\title{
PENGARUH KESELAMATAN KERJA DAN KESEHATAN KERJA TERHADAP PRODUKTIVITAS KERJA KARYAWAN PT INDONESIA POWER RANTING TANGERANG
}

\author{
${ }^{1 *}$ Budhi Prabowo, ${ }^{2}$ Elizabeth Tika Kristina Hartuti, ${ }^{3}$ Deaty Sukma Pratiwi \\ Universitas Pamulang, Tangerang Selatan, Banten, Indonesia \\ *dosen02034@unpam.ac.id
}

\begin{abstract}
Abstrak
Tujuan penelitian ini adalah untuk mengetahui pengaruh keselamatan kerja terhadap kinerja produktivitas kerja secara parsial dan simultan pada PT. Indonesia Power Ranting Tangerang. Penelitian ini bersifat Asosiatif dengan pendekatan kuantitatif. Keselamatan kerja berpengaruh positif dan signifikan terhadap produktivitas kerja hal ini dapat dibuktikan dari nilai $t_{\text {hitung }} 4,126>t_{\text {tabel }} 1,991$ dengan signifikan 0,000 $<0,05$ maka H0 ditolak dan Ha diterima. Kesehatan kerja berpengaruh positif dan signifikan terhadap produktivitas kerja hal ini dapat dibuktikan dari nilai thitung sebesar 4,226 $>t_{\text {tabel }}$ 1,991 dengan signifikan 0,000 < 0,05 maka H0 ditolak dan Ha diterima. Secara simultan keselamatan kerja dan kesehatan kerja berpengaruh positif dan signifikan terhadap produktivitas kerja hal ini dapat dibuktikan dari nilai Fhitung 36,990 $>\mathrm{F}_{\text {tabel }}$ 3,12 dengan siginifikan 0,000 $<0,05$ dengan demikian Ho ditolak dan Ha diterima.
\end{abstract}

Kata Kunci: Keselamatan Kerja, Kesehatan Kerja, Produktivitas Kerja

\section{Abstract}

The purpose of this study was to determine the effect of work safety on work productivity partially and simultaneously at PT. Indonesia Power Branch Tangerang. This research is associative with a quantitative approach. Work safety has a positive and significant effect on work productivity, this can be proven from the value of tcount $4.126>$ ttable 1.991 with a significant $0.000<0.05$ then $\mathrm{HO}$ is rejected and Ha is accepted. Occupational health has a positive and significant effect on work productivity, this can be proven from the tcount value of 4.226 $>$ ttable 1.991 with a significant $0.000<0.05$ then $\mathrm{HO}$ is rejected and Ha is accepted. Simultaneously, occupational safety and health have a positive and significant effect on work productivity, this can be proven from the value of Fcount $36.990>$ Ftable 3.12 with a significance of $0.000<0.05$, thus Ho is rejected and Ha is accepted.

Keywords: Work Discipline, Motivation, Employee Performance

\section{PENDAHULUAN}

Dalam era globalisasi seperti ini sektor industri memegang peranannya sangat penting dalam kehidupan manusia. Hal ini terjadi karena banyaknya persaingan di dunia kerja. Sektor industri merupakan sektor yang mampu menyerap tenaga kerja yang cukup besar. Perkembangan teknologi harusnya juga diiringi dengan keselamatan karyawan. Akhir-akhir ini banyak kecelakaan di dunia kerja. Untuk itu diperlukan pengawasan serta penggunaan alat-alat yang dapat melindungi diri dari kecelakaan kerja, karena pada dasarnya keselamatan karyawan merupakan hal yang sangat penting untuk menunjang kemajuan industri. Kecelakaan kerja memberikan dampak yang buruk terhadap pekerja, lingkungan, masyarakat dan industri. Akibat dari kecelakaan kerja dapat merugikan perusahaan yaitu terlambatnya proses produksi dan terganggungnya aktivtas kerja serta biaya yang dikeluarkan saat terjadinya kecelakaan seperti biaya rumah sakit yang harus ditanggung perusahaan, sedangkan pada karyawan dan masyarakat dapat mengalami kecacatan fisik beupa kecacatan non permanent maupun kecacatan yang permanen.

Salah satu cara pemeliharaan terhadap sumber daya manusia adalah dengan membuat program khusus yang menangani tentang kesehatan dan 
keselamatan kerja (K3) dalam perusahaan. Pembuatan program K3 dalam suatu perusahaan bertujuan untuk melindungi tenaga kerja dari segala resiko pekerjaan seperti gangguan kesehatan dan kecelakaan kerja. Program keselamatan dan kesehatan kerja (K3) sangatlah penting dalam suatu perusahaan. Menurut Ridley (2015:104), "tanpa adanya program keselamatan dan kesehatan kerja (K3) motivasi dan antusiasme pekerja dapat menguap dengan cepat, kegiatan keselamatan kerja pun bisa berangsur-angsur melemah dan akhirnya berhenti". Kesehatan dan keselamatan kerja (K3) sangat penting bagi setiap individu dalam suatu perusahaan. Kesehatan juga menjadi faktor penting dalam menjaga kelangsungan hidup sebuah organisasi.

Program kesehatan dan keselamatan kerja (K3) merupakan upaya perusahaan dalam memenuhi kebutuhan akan rasa aman terhadap tenaga kerjanya. Apabila tenaga kerja mendapat jaminan kesehatan dan keselamatan kerja (K3), tenaga kerja akan merasa aman dan nyaman sehingga dapat bekerja secara optimal. Pelaksanaan program keselamatan dan kesehatan kerja sering dianggap sepele oleh beberapa perusahaan karena dianggap akan mengurangi pendapatan perusahaan. Saat ini banyak terjadi kecelakaan akibat kerja karena beberapa penyebab terjadinya kecelakaan kerja seperti kurangnya kesadaran akan keselamatan dan kesehatan di tempat kerja, alat pelindung diri yang tidak lengkap dan sebagainya.

Produktivitas kerja merupakan tujuan yang sangat penting dalam perusahaan, melalui produktivitas akan dapat diketahui keadaan dari suatu perusahaan, dengan berbagai cara terlepas dari tujuannya, misinya, jenisnya, strukturnya, dan ukurunnya. Banyak cara untuk meningkatkan produktivitas kerja karyawan antara lain melalui pendidikan dan pelatihan, teknologi dan hasil produksi, kesehatan, kemampuan fisik dan mental. Menurut Sedarmayanti (2012:56), "produktivitas adalah keinginan (the will) dan upaya (effort) manusia untuk selalu meningkatkan kualitas kehidupan dan penghidupannya di segala bidang. Secara umum produktivitas mengandung pengertian perbandingan antara hasil yang dicapai (output) dengan keseluruhan sumber daya yang digunakan (input)".

PT. Indonesia Power adalah salah satu anak perusahaan PT. PLN (Persero) yang merupakan Perusahaan Pembangkit Tenaga Listrik dengan total kapasitas terpasang sekitar $9000 \mathrm{MW}$ dan memiliki delapan unit bisnis pembangkitan yang tersebar di Pulau Jawa dan Bali, serta satu unit bisnis Jasa pemeliharaan.

\section{TINJAUAN PUSTAKA}

\section{Keselamatan kerja}

Menurut Mangkunegara

(2016:156)," keselamatan kerja menunjukkan pada kondisi yang aman atau selamat dari penderitaan, kerusakan atau kerugian di tempat kerja". Berdasarkan pendapat para ahli diatas maka dapat disimpulkan bahwa keselamatan kerja adalah suatu perlakuan yang diberikan oleh perusahaan kepada karyawan berupa perlindungan dari kemungkinan adanya bahaya yang timbul dari lingkungan kerja agar karyawan merasa aman dan nyaman dalam bekerja yang dapat berpengaruh pada kualitas kerja karyawan.

2. Kesehatan kerja

Menurut Widodo (2015:89) kesehatan kerja adalah suatu kondisi kesehatan yang bertujuan agar masyarakat pekerja memperoleh derajat kesehatan setinggi-tingginya, baik jasmani, rohani maupun sosial dengan usaha pencegahan dan pengobatan terhadap penyakit atau gangguan kesehatan yang disebabkan oleh pekerja dan lingkungan kerja maupun penyakit umum.

\section{Produktivitas kerja}

Menurut Sondang $\mathrm{P}$ Siagian (2013:15) "Produktivitas kerja adalah kemampuan memperoleh manfaat sebesar-besarnya dari sarana dan 
prasarana yang tersedia dengan menghasilkan output yang optimal, kalau mungkin yang maksimal". Sehubung dengan hal tersebut, konsep produktivitas pada dasarnya mencakup sikap mental dan perilaku yang berorientasi pada perbaikan berkelanjutan (continius improvement), dan mempunyai pandangan bahwa kinerja hari ini harus lebih baik dari hari kemarin, dan kinerja hari esok harus lebih baik dari prestasi hari ini.

\section{METODE}

Penelitian ini bersifat Asosiatif dengan pendekatan kuantitatif. Populasi dalam penelitian ini adalah seluruh karyawan PT. Indonesia Power Ranting Tangerang yang berjumlah 80 responden. Jenis penelitian yang dipakai adalah kuantitatif, dimana tujuannya adalah untuk mengetahui pengaruh antara variabel bebas terhadap variabel terikat baik parsial maupun simultan Dalam menganalisis data digunakan uji instrumen, uji asumsi klasik, regresi, koefisien korelasi, koefisien determinasi dan uji hipotesis.

\section{HASIL DAN PEMBAHASAN}

\section{Uji Validitas}

Menurut Sugiyono (2015:267) "validitas merupakan derajat ketepatan antara data yang terjadi pada obyek penelitian dengan data yang dapat dilaporkan oleh peneliti". Uji validitas digunakan untuk menguji pertanyaan maupun pernyataan pada kuesioner yang disebar apakah valid atau tidak. Caranya dengan membandingkan antara $r_{\text {hitung dengan } r_{\text {tabel }} \text { dengan tingkat }}$ kesalahan (signifikan) 5\%. Sedangkan nilai $r_{\text {tabel }}$ dalam penelitian ini dengan signifikasi 0,05 dan jumlah Sampel $n=80$ adalah:

Degre Of Freedom $=\mathrm{n}-2$

Degre Of Freedom $\quad=80-2=78$

Jadi $r_{\text {tabel }}$ adalah $=0,219$ (terlampir uji r)

Dasar pengambil keputusannya adalah sebagai berikut:

1) Bila nilai $r_{\text {hitung }}>r_{\text {tabel, }}$ maka item pertanyaan valid.

2) Bila nilai $r_{\text {hitung }}<r_{\text {tabel, }}$ maka item pertanyaan tidak valid.

Ukuran validitas tiap butir-butir pernyataan dapat dilihat dalam tabel di bawah ini:

Tabel 1. Uji Validitas Keselamatan Kerja $\left(X_{1}\right)$

\begin{tabular}{c|c|c|c|} 
Pernyataan & Nilai rhitung & Nilai rtabel & Keterangan \\
\hline Pernyataan 1 & 0,889 & 0,219 & Valid \\
\hline Pernyataan 2 & 0,898 & 0,219 & Valid \\
\hline Pernyataan 3 & 0,976 & 0,219 & Valid \\
\hline Pernyataan 4 & 0,955 & 0,219 & Valid \\
\hline Pernyataan 5 & 0,895 & 0,219 & Valid \\
\hline Pernyataan 6 & 0,837 & 0,219 & Valid \\
\hline \multicolumn{4}{|c}{ Berdasarkan hasil uji }
\end{tabular}
validitas tersebut maka dapat diketahui bahwa keseluruhan nilai $r_{\text {hitung }}>r_{\text {tabel }} 0,219$, dengan demikian maka dapat disimpulkan bahwa semua item pernyataan dalam indikator variabel keselamatan kerja adalah valid. Sehingga tidak ada item pernyataan yang dihapus dan semua item pernyataan dapat digunakan pada keseluruhan model pengujian ini.

\section{Analisis Kuantitatif}

Pada analisis ini dimaksudkan untuk mengetahui pengaruh variabel independen terhadap variabel dependen. Adapun hasil pengujian sebagai berikut:

\section{a. Analisis Regresi Linier Berganda}

Tabel 2. Regresi Linier Berganda

Coefficients ${ }^{a}$

\begin{tabular}{|c|c|c|c|c|c|c|}
\hline \multirow{2}{*}{\multicolumn{2}{|c|}{ Model }} & \multicolumn{2}{|c|}{ Unstandardized Coefficients } & \multirow{2}{*}{$\begin{array}{c}\text { Standardized Coefficients } \\
\text { Beta }\end{array}$} & \multirow{2}{*}{$\mathrm{t}$} & \multirow{2}{*}{ Sig. } \\
\hline & & B & Std. Error & & & \\
\hline \multirow{3}{*}{1} & (Constant) & 27175 & 2622 & & 10366 & 0,000 \\
\hline & Keselamatan kerja & 0,387 & 0,094 & 0,396 & 4126 & 0,000 \\
\hline & Kesehatan kerja & 0,341 & 0,081 & 0,405 & 4226 & 0,000 \\
\hline
\end{tabular}


Berdasarkan hasil perhitungan tersebut maka dapat diperoleh persamaan regresi linier berganda $Y=$ $27,175+0,387 X_{1}+0,341 X_{2}$

b. Analisis Koefisien Korelasi

Korelasi menjelaskan tentang tingkat keeratan hubungan suatu

Tabel 3. Koefisien Korelasi

\section{Correlations}

Produktivitas Keselamatan kerja Kesehatan kerja

\begin{tabular}{llrrrr}
\hline \multirow{3}{*}{ Pearson Correlation } & Produktivitas & 1000 &, 610 &, 614 \\
\cline { 2 - 5 } & Keselamatan kerja &, 610 & 1000 &, 529 \\
\cline { 2 - 5 } & Kesehatan kerja &, 614 &, 529 & 1000 \\
\cline { 2 - 5 } Sig. (1-tailed) & Produktivitas &. &, 000 &, 000 \\
\cline { 2 - 5 } & Keselamatan kerja &, 000 & .000 &, 000 \\
\cline { 2 - 5 } & Kesehatan kerja &, 000 & 80 &. \\
\cline { 2 - 6 } N & Produktivitas & 80 & 80 & 80 \\
\hline & Keselamatan kerja & 80 & 80 & 80 \\
\cline { 2 - 5 } & Kesehatan kerja & 80 & & \\
\hline
\end{tabular}

Berdasarkan nilai korelasi yang di dapat maka dapat diketahui bahwa:

a. Nilai korelasi keselamatan kerja $\left(\mathrm{X}_{1}\right)$ sebesar 0,610 nilai ini masuk pada interval 0,60 - 0,799 artinya bahwa tingkat hubungan keselamatan kerja $\left(X_{1}\right)$ terhadap produktivitas $(\mathrm{Y})$ memiliki tingkat hubungan yang kuat.

b. Nilai korelasi kesehatan kerja $\left(\mathrm{X}_{2}\right)$ sebesar 0,614 nilai ini masuk pada

Tabel 4. Koefisien Determinasi Keselamatan Kerja $\left(\mathrm{X}_{1}\right)$ Terhadap Produktivitas $(\mathrm{Y})$

Model Summary

\begin{tabular}{lc|r|r|r} 
Model & R & R Square & Adjusted R Square & Std. Error of the Estimate \\
\hline 1 &, $610 \mathrm{a}$ & 0,372 & 0,364 & 625,724 \\
\hline
\end{tabular}

a. Predictors: (Constant), Kesehatan kerja, Keselamatan kerja

b. Dependent Variable: Produktivitas

Berdasarkan tabel di atas, dapat diketahui bahwa besarnya nilai koefisien determinasi ditunjukkan oleh nilai $R$ Square yaitu sebesar 0,372 artinya variabel keselamatan kerja $\left(\mathrm{X}_{1}\right)$ memberikan kontribusi terhadap

Tabel 5. Koefisien Determinasi Kesehatan Kerja $\left(\mathrm{X}_{2}\right)$ Terhadap Produktivitas $(\mathrm{Y})$ Model Summary

\begin{tabular}{lc|c|c|c|} 
Model & $\mathrm{R}$ & R Square & Adjusted R Square & Std. Error of the Estimate
\end{tabular}

\begin{tabular}{rrrrr}
\hline 1 &, $614 a$ & 0,377 & 0,369 & 625,724 \\
\hline
\end{tabular}

a. Predictors: (Constant), Kesehatan kerja

b. Dependent Variable: Produktivitas 
Berdasarkan tabel di atas, dapat diketahui bahwa besarnya nilai koefisien determinasi ditunjukkan oleh nilai $R$ Square yaitu sebesar 0,377 artinya variabel kesehatan kerja $\left(\mathrm{X}_{2}\right)$ memberikan kontribusi terhadap

Tabel 6. Koefisien Determinasi Simultan

Model Summary

\begin{tabular}{lc|r|r|r} 
Model & R & R Square & Adjusted R Square & Std. Error of the Estimate \\
\hline 1 &, $700^{\mathrm{a}}$ & 0,490 & 0,477 & 569,910 \\
\hline
\end{tabular}

a. Predictors: (Constant), Kesehatan kerja, Keselamatan kerja

b. Dependent Variable: Produktivitas

Berdasarkan tabel di atas, dapat diketahui bahwa besarnya nilai koefisien determinasi ditunjukkan oleh nilai $R$ Square yaitu sebesar 0,490 artinya secara simultan keselamatan kerja $\left(X_{1}\right)$ dan kesehatan kerja $\left(X_{2}\right)$ memberikan kontribusi terhadap variabel produktivitas (Y) sebesar $49 \%$, sedangkan sisanya sebesar $51 \%$ di pengaruhi oleh variabel lain yang tidak diteliti dalam penelitian ini. variabel produktivitas (Y) sebesar $37,7 \%$, sedangkan sisanya sebesar $52,3 \%$ di pengaruhi oleh variabel lain yang tidak diteliti dalam penelitian ini.

\section{d. Uji Hipotesis \\ Uji hipotesis Parsial (Uji t)}

Pengujian hipotesis dengan uji $t$ digunakan untuk mengetahui hipotesis parsial mana yang diterima. Hipotesis pertama:

$\mathrm{Ho}_{1}: \beta_{1}=0$ Tidak terdapat pengaruh yang positif dan signifikan keselamatan kerja terhadap produktivitas kerja.

$\mathrm{Ha}_{1}: \beta_{1}=0 \quad$ Terdapat pengaruh yang positif dan signifikan keselamatan kerja terhadap produktivitas kerja.

Tabel 7. Uji thitung Keselamatan Kerja ( $\left.\mathrm{X}_{1}\right)$ Terhadap Produktivitas $(\mathrm{Y})$

\begin{tabular}{lllll} 
Model & $t_{\text {hitung }}$ & $t_{\text {tabel }}$ & Sig. & Keputusan \\
\hline Keselamatan kerja & 4,126 & 1,991 & 0,000 & Signifikan \\
\hline
\end{tabular}

a. Dependent Variable: Produktivitas kerja

Berdasarkan tabel tersebut dapat diketahui bahwa nilai thitung sebesar $4,126>t_{\text {tabel }} 1,991$ dengan signifikan $0,000<0,05$ maka H0 ditolak dan $\mathrm{Ha}$ diterima artinya terdapat pengaruh yang positif dan signifikan keselamatan kerja terhadap produktivitas kerja.

Hipotesis kedua:

Tabel 8. Uji thitung Kesehatan Kerja ( $\left.\mathrm{X}_{1}\right)$ Terhadap Produktivitas ( $\mathrm{Y}$ )

\begin{tabular}{lllll} 
Model & $\mathrm{t}_{\text {hitung }}$ & $\mathrm{t}$ tabel & Sig. & Keputusan \\
\hline Kesehatan kerja & 4,226 & 1,991 & 0,000 & Signifikan \\
\hline
\end{tabular}

a. Dependent Variable: Produktivitas kerja

Berdasarkan tabel tersebut dapat diketahui bahwa nilai thitung sebesar $4,226>t_{\text {tabel }} 1,991$ dengan signifikan $0,000<0,05$ maka H0 ditolak dan $\mathrm{Ha}$ diterima artinya terdapat pengaruh yang positif dan signifikan kesehatan kerja terhadap produktivitas kerja.

\section{Uji Hipotesis Simultan (Uji F)}

Pengujian secara keseluruhan digunakan untuk mengetahui apakah 
ada pengaruh secara bersama-sama dari variabel keselamatan kerja dan kesehatan kerja terhadap produktivitas. Pengujian ini dilakukan menggunakan distribusi $\mathrm{F}$ dengan membandingkan anatara nilai

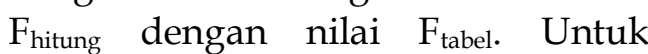
menentukan nilai $\mathrm{F}$, maka diperlukan adanya derajat bebas pembilang dan derajat bebas penyebut, dengan rumus sebagai berikut :

Degree of freedom (pembilang) $=\mathrm{k}-1$

Degree of freedom (penyebut) $=\mathrm{n}-\mathrm{k}-1$

$\mathrm{n}$ = jumlah sampel penelitian

$\mathrm{k}=$ jumlah variabel bebas dan terikat

1 = konstan

Pada penelitian ini diketahui jumlah sampel (n) 80 dan jumlah keseluruhan variabel $(\mathrm{k})$ adalah 3 , sehingga diperoleh :

Degree of freedom (pembilang) $=3-1=2$
Degree of freedom (penyebut) $=80-3-1$ $=76$

Jadi $F_{\text {tabel }}$ adalah $(0,05,76)=3,12$ (terlampir uji F)

Pada tingkat kepercayaan $95 \%$ atau $a=5 \%$ sebagai berikut:

1) Ho diterima dan $\mathrm{Ha}$ ditolak jika $\mathrm{F}_{\text {hitung }} \leq \mathrm{F}_{\text {tabel }}$ pada $\mathrm{a}=5 \%$

2) Ho ditolak dan Ha diterima jika $F_{\text {hitung }} \geq F_{\text {tabel }}$ pada $\alpha=5 \%$

Hipotesis III yang diajukan sebagai berikut:

$\mathrm{Ho}_{3}: \beta_{1} \beta_{2}=0$ Tidak terdapat pengaruh yang positif dan signifikan keselamatan kerja dan kesehatan kerja secara simultan terhadap produktivitas kerja.

$\mathrm{Ha}_{3}: \beta_{1} \beta_{2}=0$ Terdapat pengaruh yang positif dan signifikan keselamatan kerja dan kesehatan kerja secara simultan terhadap produktivitas kerja.

Tabel 9. Uji Fhitung

\begin{tabular}{rl|r|r|r|c|c} 
Model & & Sum of Squares & df & Mean Square & F & Sig. \\
\hline \multirow{3}{*}{1} & Regression & $2,402,858$ & 2 & $1,201,429$ & 36,990 &, $000^{\mathrm{b}}$ \\
\cline { 2 - 8 } & Residual & $2,500,942$ & 77 & 32,480 & & \\
\cline { 2 - 8 } & Total & $4,903,800$ & 79 & & & \\
\hline
\end{tabular}

a. Dependent Variable: Produktivitas

b. Predictors: (Constant), Kesehatan kerja, Keselamatan kerja

Berdasarkan tabel 4.24 diperoleh nilai $\mathrm{F}_{\text {hitung }} 36,990>\mathrm{F}_{\text {tabel }} 3,12$ dengan siginifikan $0,000<0,05$ dengan demikian Ho ditolak dan $\mathrm{Ha}$ diterima, artinya terdapat pengaruh yang positif dan signifikan keselamatan kerja dan kesehatan kerja secara simultan terhadap produktivitas kerja.

\section{PEMBAHASAN HASIL PENELITIAN}

1. Pengaruh Keselamatan kerja terhadap Produktivitas kerja

Keselamatan kerja berpengaruh positif dan signifikan terhadap produktivitas kerja hal ini dapat dibuktkan dari nilai regresi $0,387 \mathrm{X}_{1}$ artinya apabila variabel keselamatan kerja $\left(X_{1}\right)$ meningkat sebesar 1 satuan maka produktivitas kerja (Y) akan meningkat sebesar 0,387 satuan. Nilai korelasi keselamatan kerja $\left(\mathrm{X}_{1}\right)$ sebesar 0,610 artinya tingkat hubungan keselamatan kerja $\left(\mathrm{X}_{1}\right)$ terhadap produktivitas $(Y)$ memiliki tingkat hubungan yang kuat. Nilai $R$ Square yaitu sebesar 0,372 artinya variabel keselamatan kerja $\left(X_{1}\right)$ memberikan kontribusi terhadap variabel produktivitas (Y) sebesar 37,2\%, sedangkan sisanya sebesar $62,8 \%$ di pengaruhi oleh variabel lain yang tidak diteliti dalam penelitian ini. Nilai $t_{\text {hitung }}$ sebesar $4,126>t_{\text {tabel }} 1,991$ dengan signifikan 0,000 < 0,05 maka H0 ditolak dan Ha diterima artinya terdapat pengaruh yang positif dan signifikan keselamatan kerja terhadap produktivitas kerja. 


\section{Pengaruh Kesehatan kerja terhadap Produktivitas kerja}

Kesehatan kerja berpengaruh positif dan signifikan terhadap produktivitas kerja hal ini dapat dibuktkan dari nilai regresi $0,341 \mathrm{X}_{2}$ artinya apabila variabel kesehatan kerja $\left(X_{2}\right)$ meningkat sebesar 1 satuan maka produktivitas kerja $(\mathrm{Y})$ akan meningkat sebesar 0,341 satuan. Nilai korelasi kesehatan kerja $\left(X_{2}\right)$ sebesar 0,614 artinya tingkat hubungan kesehatan kerja $\left(\mathrm{X}_{2}\right)$ terhadap produktivitas (Y) memiliki tingkat hubungan yang kuat. Nilai $R$ Square yaitu sebesar 0,377 artinya variabel kesehatan kerja $\left(\mathrm{X}_{2}\right)$ memberikan kontribusi terhadap variabel produktivitas $(\mathrm{Y})$ sebesar 37,7\%, sedangkan sisanya sebesar $52,3 \%$ di pengaruhi oleh variabel lain yang tidak diteliti dalam penelitian ini. Nilai $t_{\text {hitung }}$ sebesar $4,226>t_{\text {tabel }} 1,991$ dengan signifikan 0,000 < 0,05 maka H0 ditolak dan $\mathrm{Ha}$ diterima artinya terdapat pengaruh yang positif dan signifikan kesehatan kerja terhadap produktivitas kerja

\section{Pengaruh Keselamatan kerja dan \\ Kesehatan kerja terhadap \\ Produktivitas kerja}

Keselamatan kerja dan kesehatan kerja secara simultan berpengaruh positif dan signifikan terhadap produktivitas kerja hal ini dapat dibuktkan dari nilai $R$ Square yaitu sebesar 0,490 artinya secara simultan keselamatan kerja $\left(X_{1}\right)$ dan kesehatan kerja $\left(X_{2}\right)$ memberikan kontribusi terhadap variabel produktivitas $(\mathrm{Y})$ sebesar $49 \%$, sedangkan sisanya sebesar $51 \%$ di pengaruhi oleh variabel lain yang tidak diteliti dalam penelitian ini. Nilai $F_{\text {hitung }} 36,990>F_{\text {tabel }} 3,12$ dengan siginifikan 0,000 $<0,05$ dengan demikian Ho ditolak dan Ha diterima, artinya terdapat pengaruh yang positif dan signifikan keselamatan kerja dan kesehatan kerja secara simultan terhadap produktivitas kerja.

\section{KESIMPULAN}

1. Keselamatan kerja berpengaruh positif dan signifikan terhadap produktivitas kerja hal ini dapat dibuktikan dari nilai $t_{\text {hitung }} 4,126>t_{\text {tabel }} 1,991$ dengan signifikan $0,000<0,05$ maka H0 ditolak dan Ha diterima.

2. Kesehatan kerja berpengaruh positif dan signifikan terhadap produktivitas kerja hal ini dapat dibuktikan dari nilai thitung sebesar 4,226 > tabel 1,991 dengan signifikan 0,000 < 0,05 maka H0 ditolak dan Ha diterima.

3. Keselamatan kerja dan kesehatan kerja berpengaruh positif dan signifikan terhadap produktivitas kerja hal ini dapat dibuktikan dari nilai $F_{\text {hitung }} 36,990$ $>\mathrm{F}_{\text {tabel }} 3,12$ dengan siginifikan $0,000<$ 0,05 dengan demikian Ho ditolak dan Ha diterima.

\section{SARAN}

1. Karyawan perlu diberlakukan peraturan wajib memakai alat pelindung diri, memberikan peralatan keselamatan kerja yang lengkap dan memenuhi standar keselamatan serta yang terpenting penanganan secara tepat oleh pihak perusahaan

2. Pimpinan perusahaan perlu memperhatikan secara serius kesehatan karyawannya dengan mengadakan pemeriksaan kesehatan secara berkala

3. Perusahaan perlu memberikan penghargaan bagi karyawan yang berprestasi. Bentuk-bentuk penghargaan tidak harus berupa uang, namun juga berupa pujian yang proporsional dengan prestasi sehingga pegawai dapat terus terpacu dalam bekerja.

\section{DAFTAR PUSTAKA}

Abu, Nadhir, 2017, Pengaruh Pengelolaan Keselamatan dan Kesehatan Kerja Terhadap Produktivitas Kerja Pada Pekerjaan Konstruksi Gedung di CV. Pilar Blitar Mapan Sejahtera, Jurnal Qua Teknika, Vol 7 No 1 Maret 2017, ISSN 2088-2424 (cetak); 2527-3892 (elektronik). 
Anwar, Prabu Mangkunegara, 2016, Manajemen Sumber Daya Manusia, PT. Remaja Rosdakarya, Bandung.

Ari, Andriyas Puji, 2016, Pengaruh Keselamatan dan Kesehatan Kerja Terhadap Produktivitas Menggunakan Structural Equation Modeling (Studi Kasus PT. Mataram Tunggal Garment Yogyakarta), Jurnal Fakultas Teknologi Industri Program Studi Teknik Industri UII 2016.

Bambang, Kusriyanto, 2013, Meningkatkan Produktivitas Karyawan, Seri Manajemen, LPES, Jakarta

Edy, Sutrisno, 2016, Manajemen Sumber Daya Manusia, Prenadamedia Group, Jakarta.

Ghozali, Imam, 2012, Aplikasi Analisis Multivariate dengan Program IBM SPSS, Universitas Diponegoro, Semarang.

Hadari, Nawawi, 2012, Manajemen Sumber Daya Manusia Untuk Bisnis yang. Komptitif, Gadjah Mada University Press, Yogyakarta.

Hartono, 2014, Manajemen Personalia dan Sumber Daya Manusia. Edisi Kedua. Cetakan Kedelapan belas. Penerbit BPFE. Yogyakarta.

Hasibuan, Malayu, 2016, Manajemen Sumber Daya Manusia. Edisi. Revisi. Penerbit PT Bumi Aksara, Jakarta

I. Komang Ardana, 2012, Manajemen Sumber Daya Manusia. Graha ilmu, Yogyakarta.

Indra, Novri Setiawan, 2013, Pengaruh Keselamatan Dan Kesehatan Kerja Terhadap Produktivitas Karyawan Pada Departemen Jaringan PT PLN (PERSERO) Area Surabaya Utara, Jurnal Ilmu Manajemen Volume 1 Nomor 2 Maret 2013.

Kosasih, K., et al. (2020). The Effect of Compensation and Service Period on Employee Performance at PT. Infomedia Nusantara Branch Bandung. Kontigensi: Jurnal Ilmiah Manajemen, 8(2), 147-154.

Mathis dan Jackson, 2012, Manajemen Sumber Daya Manusia, Edisi Pertama Salemba Empat, Jakarta.
Muhammad, Busyairi, La Ode Ahmad Safar Tosungku dan Ayu Oktaviani, 2014, Pengaruh Keselamatan Kerja dan Kesehatan Kerja Terhadap Produktivitas Kerja Karyawan, Jurnal Ilmiah Teknik Industri, Vol. 13, No. 2, Des 2014. ISSN 1412-6869.

Nisaul, Fitriani, Panji, Deoranto, dan Wike, Agustin Prima Dania, 2013, Analisis Pengaruh Keselamatan dan Kesehatan Kerja (K3) Terhadap Produktivitas Tenaga Kerja Dengan Metode Partial Least Square, Jurnal Industria 2013. Vol 2 No 2: 93 - 104. Analisis K3.

Pangabean, Mutiara, 2012, Manajemen Sumber Daya Manusia, Ghalia Indonesia, Jakarta.

Paramita dan Wijayanto, 2012, Pengaruh Keselamatan dan Kesehatan Kerja Terhadap Prestasi Kerja Karyawan PT PLN (Persero) APJ Semarang. Jurnal Administrasi Bisnis, 1(1): 1-7.

Ridley, 2015, Ikhtisar Kesehatan $\mathcal{E}$ Keselamatan Kerja, Edisi Ketiga. Erlangga, Jakarta.

Saputra, Andri, 2014, Pengaruh Keselamatan Kerja terhadap Produktivitas Kerja Karyawan pada PT Buran Nusa Respati di Kecamatan Anggana Kabupaten Kukar, eJournal Ilmu Pemerintahan, 20142 (3): 3059-3069 ISSN 2338-3651 eJournal.ip.fisip.unmul.ac.id.

Sedarmayanti, A. et al(2021). The Role Of Knowledge Management And Innovation Management On Manufacturing Performance. Turkish Journal of Physiotherapy and Rehabilitation, 32, 3.

Seta, A. B., et al. (2021). Pengaruh Pelatihan Dan Kompensasi Terhadap Prestasi Kerja Yang Berdampak Pada Kinerja Karyawan Pada PT Cipta Mega Sarana Di Jakarta. Jurnal Ekonomi Efektif, 4(1), 148-159. 